Relations industrielles

Industrial Relations

\title{
An Outlook on Labour Relations in Canada
}

\section{A. W.R. Carrothers}

Volume 38, numéro 3, 1983

URI : https://id.erudit.org/iderudit/029383ar

DOI : https://doi.org/10.7202/029383ar

Aller au sommaire du numéro

Éditeur(s)

Département des relations industrielles de l'Université Laval

ISSN

0034-379X (imprimé)

1703-8138 (numérique)

Découvrir la revue

Citer cet article

Carrothers, A. W. (1983). An Outlook on Labour Relations in Canada. Relations industrielles / Industrial Relations, 38(3), 648-657.

https://doi.org/10.7202/029383ar
Résumé de l'article

The object of this paper is to examine the conditions of labour relations in Canada, with a view to trying to assess what is likely to happen in the next few years; and to try to identify what review of policies and practices might be considered in an effort to ameliorate the present unhappy condition of Canadian labour relations.
Tous droits réservés @ C Département des relations industrielles de l'Universite Laval, 1983
Ce document est protégé par la loi sur le droit d'auteur. L’utilisation des services d'Érudit (y compris la reproduction) est assujettie à sa politique d'utilisation que vous pouvez consulter en ligne.

https://apropos.erudit.org/fr/usagers/politique-dutilisation/ 


\section{An Outlook on Labour Relations in Canada}

\section{A.W.R. Carrothers}

The object of this paper is to examine the conditions of labour relations in Canada, with a view to trying to assess what is likely to happen in the next few years; and to try to identify what review of policies and practices might be considered in an effort to ameliorate the present unhappy condition of Canadian labour relations.

The object of this paper is to examine the conditions of labour relations in Canada, with a view to trying to assess what is likely to happen in the next few years; and to try to identify what review of policies and practices might be considered in an effort to ameliorate the present unhappy condition of Canadian labour relations.

The assessments are based on an appraisal of power and responsibility. The significance of those words should become clear as the paper develops.

It is simplistic, but I think for present purposes useful, to recognize the principal performers in the contest of power and responsibility as management; organized labour; and government, in its many and competing roles.

\section{LABOUR RELATIONS «SYSTEM»}

The fundamentals of the Canadian labour relations system are not unique to Canada. We live in a political democracy, and we operate in a political economy that is a mixture of private enterprise, public enterprise and government regulation of business. Collective bargaining has emerged as a natural and necessary product of that environment. The employee component of the labour factor of production has combined, in the pursuit of its self-interest, to compete with other parts of the labour factor and with other factors of production, over the distribution of the rewards of the system.

If collective bargaining did not exist, the benefits gained by organized labour would, as a political reality, have to be provided by the state through

* CARROTHERS, A.W.R., Dean Common Law Section, Faculty of Law, University of Ottawa, Ottawa.

Relat. ind., vol. 38, no 3, 1983 ( ) PUL ISSN 0034-379 X 
intervention in the enterprise system. That, essentially, is the rationale of the statement that "collective bargaining is a natural concomitant of private enterprise».

Yet, in fact, the bulk of private entrepreneurs and the managers of the system in this country are far from committed to the reality of, or the need for, the collective bargaining system, and union leaders know it. That tells one something at the outset about the distribution of power and the perception of responsibility in the system.

\section{CRISES IN MODERN TIMES}

In the first half of the 1960s, the Economic Council of Canada was presented with the task of pursuing, as fully as possible, simultaneously and consistently and in the fairly short term, the basic economic and social goals of full employment, a high rate of economic growth, reasonable stability of prices, a viable balance of payments, and an equitable distribution of rising incomes. In 1983 we must ask why we have fallen so dismally short of what we sought to do.

In the summer of 1966 there was a strike on the St. Lawrence Seaway in the pursuit of so-called wage parity of Canadian employees, earning Canadian dollars, with employees being paid in U.S. dollars on the other side of the Waterway. The conflict was settled by a wage increase of $30 \%$, and similar terms brought an end to a strike on the Montréal docks. These settlements induced a railway strike that August, which ended in a statute passed by a special session of Parliament prescribing procedures which resulted in an imposed settlement. These events produced the Prime Minister's Task Force on Labour Relations, appointed to make a comprehensive review of national labour policy, with particular emphasis on the public interest.

Three disputes produced a state of alarm and a national inquiry.

Since that time the country has witnessed postal strikes; air transportation strikes; major turbulence in the nickel and other base metal industries; ferry strikes on both coasts; major strikes of Ontario hospital workers and school teachers; the closing of the Port of Vancouver; turbulence in Québec which saw the confrontation of the government's solvency by the Common Front and the ultimate jailing of labour leaders for contempt of court, and major strikes by policemen, firemen, school teachers and metro workers in that province; the election of an NDP government in British Columbia which brought in major revisions to the legal framework of collective bargaining and which, after three years in office, was turfed out by an electorate disaffected by labour conflict; the introduction of federal antiinflation regulations in 1975 which alienated the labour movement from participation in policy reviews; a serious recession, bankruptcies, a shocking level of unemployment, and $22 \%$ interest rates; the present federal 6 and 5 policy which has been adopted elsewhere in Canada, the Ontario 5 and 4 policy, and legislative action in Québec to reduce public service incomes; and the open admission by governments that the economy of the country is 
heavily dependent upon the economic condition of the United States and is largely beyond government control. That's a long sentence. We are serving it. When can we expect parole? Who, now, has a right to a hearing?

At the senior level of the trade union movement, organized labour has withdrawn from public and private bodies where matters of public policy may be examined collectively and acceptable solutions explored.

There is no cry for a public inquiry into national labour policy, and I expect that any such cry would be ignored. Yet the Canadian economy is now in the worst shape it has been in within the memory of most of the Canadian electorate.

What were some of the problems the Task Force looked into in 1967? A few examples will do: commitment to and acceptance of the system of collective bargaining; industrial democracy and the rule of law in the workplace; collective bargaining and economic efficiency, the labour market, equity in the distribution of income, and industrial conversion; and public inconvenience and hardship. What were some of the subjects of its recommendations in 1969? Freedom to associate and to act collectively; union and management rights and responsibilities; the public interest in industrial conflict and the results of collective bargaining; and the roles of government.

The issues are much the same today. The conditions are incomparably worse.

\section{CRISIS TODAY: THE PERFORMERS}

Employers are frustrated, confused and frightened. They can no longer pass costs on to consumers, yet they cannot take strikes in what to them has become a non-competitive market environment. They are dealing with organized labour which in many sectors appears to demonstrate little if any respect for the concept of the bottom line.

Organized labour is frustrated, confused and frightened. A significant number of senior labour leaders are alienated to the point where they have gone into permanent opposition to governments and to the present economic and political system. They seek to operate through political action, yet have not so far been able to deliver the vote of the rank-and-file. The NDP has never formed a federal government and has no immediate prospect of doing so. It has formed governments in two provinces, one Saskatchewan, which is not exactly the heartland of industrial Canada, and the other British Columbia, where the government fell in the incredible nightmare of labour conflict in 1975.

\section{CRISIS TODAY: THE PUBLIC}

There has in the last decade been a steady rise of public intolerance of strikes in the tertiary or service sector of the economy. It is not surprising. 
Before World War II, over half of Canada's GNP was generated from agriculture. The law of labour-management relations in this country has its roots in the primary sector of the economy just after the turn of the century, mainly in mining and in the forest products industry, where a significant presence at one end of the country was bolshevism and anarchy, and at the other end domination of the labour movement by the Church. But labour policy was not really a major national concern, and Labour Canada is still a junior ministry.

Outside the agricultural sector, the pre-war economy of Canada was rooted in basic industries, mainly in the exploitation of non-recurring natural resources. During the war the economy shifted upward to the secondary or manufacturing sector, which was characterized by stability in employment and absence of mobility in the labour force. War-time labour policy, which had a tremendous influence on post-war legislation, was largely shaped by and directed to the secondary sector. The economy has moved a long way from there.

An increasing proportion of the GNP is derived from the tertiary or service sector. As it has become more important, labour relations in that sector have taken on increased significance. A major distinction of labour relations in the tertiary sector is that in a situation of conflict, economic sanctions are addressed not against the protagonists to the dispute, but against the public. I use the word public in two senses: first, as the collectivity of private interests; and second, as representing the general well-being of the country. It is no wonder that since the introduction of legislation in Parliament in 1950 to bring an end to the railway strike and to impose compulsory arbitration, there have been over a hundred instances of special laws enacted to terminate work stoppages in the service sector which, when they started, were lawful strikes.

Ad hoc legislation to change the rules of collective bargaining now appears to be part of our national labour policy. It is part of our «arsenal of weapons». That in itself should not be surprising, because one cannot determine $a$ priori whether a work stoppage in the service sector is against the public interest. Yet we have a highly structured legal framework for collective bargaining addressed mainly to the needs of the secondary sector of the economy. And we have an economy that has progressed and is continuing to progress from an agricultural base, through the exploitation of natural resources, through a secondary industrial base, to a significant reliance on the service sector.

The country consists of five distinct economic regions: the Atlantic region, Central Canada, the Prairies, the far West, and the Canadian North. Each has its own economic and labour relations configurations. Superimposed on the economic regions are 13 political jurisdictions. Is it surprising that there is a policy of ad hoc emergency modifications to a comparatively rigid labour relations system, embodied in legislation enacted in the name of the public interest? 


\section{CAN YOU NAME THE PUBLIC INTEREST?}

What, in all this, do we understand to be the nature of the public interest? Should it be limited to questions of health and public safety? Should it extend to economic well-being? Should it embrace matters of convenience as well as necessity or emergency or essentiality? What is public convenience, or public necessity? Should the public interest embrace political and social well-being, including maintenance of the rule of law and preservation of the state, in addition to personal or economic interests? Is the term "public interest» anything more than a moralistic image of the outward limits of public tolerance, the location of which is itself susceptible to all the vagaries of circumstance, including the availability and use of instruments of psychological advantage? Is there a criterion, or even a set of criteria, by which it can be said with confidence, before an impasse in a given dispute, that a stoppage of production or services would be contrary to the public interest? If not, by what procedure, or through what machinery, can such a determination be made as the need arises?

Who should be charged with responsibility for deciding that a need has arisen? Into whose hands should the procedures and the machinery for determination be placed? What are the causes of such disputes? Are they identifiable or are they too diffuse to permit useful classification? What effective alternatives are there to work stoppages? Which choice or choices of solution are most consonant with present-day values and aspirations?

Challenging responses to each of these questions is the public interest in the very system of collective bargaining as an instrument for the pursuit of social and economic justice.

Effective and acceptable answers to these questions must be found. Yet at present there is no reasonable expectation of effective dialogue on these issues, and there will be none so long as a significant number of senior labour leaders maintain a stance of alienation and opposition. What is the self-image of the country's labour leaders? How would one expect them to behave?

\section{RESPONSIBILITY: BY WHOM, TO WHOM, AND FOR WHAT?}

I think it is important to understand why alienation has emerged to destroy effective communication on issues of public policy. Here is where an understanding of the element of responsibility becomes important.

When the labour movement arose from the ashes of the Knights of Labour in the United States in the 1880s, a cigar maker by the name of Samuel Gompers built the American Federation of Labour on a determination that labour's responsibility is to itself and itself alone, and labour must in no way be responsible for the health of enterprise. They were competitors for the spoils of production, and labour's slogan was «More, more, more now». During the 1930s organized labour became identified with the Democratic Party and the New Deal. It experienced political responsibility. 
And it accepted that the well-being of the labour movement related to the well-being of the economy, whatever party formed the government.

In the United Kingdom the labour movement created the Labour Party. It knows first-hand the responsibilities of elective public office. The labour movement in that country has made and broken more than one government in our time.

If one were to investigate the industrial relations system in West Germany, one would meet without question a labour representative on a board of directors. Only as an afterthought and on request would one meet a shop steward from the plant floor. That speaks volumes about the nature of responsibility in the West German industrial relations system of «codetermination».

Visit Sweden. There is a triumvirate of labour, management and government, highly sensitive to the nature and conditions of the economy.

In Japan, a person on entering the labour force takes employment with a particular employer with the prospect of making a life-time career in the industry. The employer accepts a correlative responsibility for the welfare of its employees. There is a community of interest which we have not experienced, even in wartime.

In Canada, the labour movement has not known the responsibilities of elective public office, except in some measure for the abortive experience in British Columbia and the not highly relevant experience in Saskatchewan. It has never really broken away from the limited pragmatism of Samuel Gompers, even though it speaks out on social issues, both domestic and international, and has played a part in such organizations as the National Productivity Council, its successor the Economic Council of Canada, and nominally in various organizations in the private sector such as The Conference Board and the C.D. Howe Institute.

But the labour movement participated at will, and pulled out at will, believing that emergency policies of the government of the day ran counter to the interests of organized labour. Furthermore, it knows that public opinion is hostile to strikes in the service sector and that it is hostage to public opinion. Collective bargaining has become a political phenomenon, as it has been in Quebec for a long time and for reasons other than economic maturation. Is it surprising that the Ontario Labour Relations Board recently determined that political campaigning at the workplace by a certified bargaining authority - that is, a union - was an abuse of the certification?

Perhaps it is now clearer why today's immediate problems may be assessed in terms of perceptions of power and responsibility, of and by all three performers: labour, management and government. And government must be recognized as being assigned the interdependent and sometimes conflicting roles of determiner of national labour policy, administrator of the industrial relations system, resolver of particular disputes in the name of the public interest, and employer per se. The settlement of the postal strike of 1969 required the reconciliation of the conflicting interests of five federal ministries. 


\section{THE HIGH COST OF MUSTARD PLASTERS}

What can be done? I see no meaningful solutions in tinkering with the legal framework of collective bargaining. Compulsory supervised strike votes have been tried and bear their own mischief. Counting as negative strike votes those employees who fail to vote merely loads the ballotting against a strike, without contributing anything to reaching a solution - in fact it might even aggravate conflict by depriving the work force of one of its essential freedoms within the system: the freedom to strike. In British Columbia in 1973 a major legislative shift was made to take labour conflict out of the courts and put it under the jurisdiction of the Labour Relations Board. The reform changed the rules and the centres of activity. But I am far from convinced that the basic nature of labour relations changed, or that the resolution of industrial conflict has improved.

\section{LABOUR POLICY AND PUBLIC PLANNING}

All of the foregoing is a background to an assertion of the need to make a review of national labour policy affecting a wide range of public issues. Although the issues have a heavy economic and social content, the selection of alternatives is a political act.

Not so very long ago social and economic planning was a highly evocative term; to those who were wedded to the political, economic and social philosophy of laissez-faire it was poison. It is difficult to deny its respectability today. As the world emerged from the depression of the 1930s, people declared, «This must not be allowed to happen again». The asking of the question «By whom?» marked the beginning of general recognition that economic and social planning is the proper province of governments. Yet it is happening again.

I offer seven factors of policy and reality in social and economic planning which ought to be explored, with a view to identifying labour relations policies.

1. The policy of collective bargaining itself as a strategy of labourmanagement relations.

2. The realities of, and the variations within, the capitalist system.

3. The realities of and dependence on international trade for Canacla.

4. Fiscal and monetary policy, including control of inflation, the regulation of prices and incomes, and the stability of the Canadian dollar.

5. Labour market policy, especially the question of high unemployrnent and its many derivative issues, including manpower retraining and the general encouragement of upward mobility in the labour force, and the electronic revolution and its impact on the growth of the service sector of the economy.

6. Policy respecting the social infrastructure with particular reference to social and economic security and opportunity.

7. Productivity policy and economic growth. 
In a political democracy, actions taken by a government to shape or control the seven factors will in turn be shaped by prevailing values respecting human worth and dignity and individual liberty, and will reflect the pervading concept of the state.

Where these matters, combined with serious review of the nature of the public interest, to receive committed attention, it may well be that one will be able to revive an attitude of trust and co-operation among senior members of the labour movement, and within governments.

\section{YOU CAN'T GO HOME AGAIN}

All the foregoing is quite conventional. It is an analytical framework based on power and responsibility through which one may consider for the immediate term such issues as productivity, competition, wage stability, mutual commitment, job security, growth, and expectation, in the context of free enterprise. It is premised on what authors of scenarios for the unfolding universe call a surprise-free future. Yet it is the surprises in the future which we must control, or to which we must adapt.

What and whom do people care about? They care about what is going to happen to them. That should be the focus of our outlook.

I am not a seer and I have no desire to be one, if for no other reason than that their record of survival has not been impressive. Nor am I a futurist, although there are many good ones, and the insights of the best of them are entitled to careful appraisal.

Who expects the economy to recover in the sense of regaining the configuration that society and the economy had in the 1960s? What is the blueprint for reconstruction to reconstruct? a period piece?

Consider the condition of our basic industries. Canada no longer holds the trump cards in the world supply of nickel. We have vast iron deposits, but so has the rest of the world, and the markets are drifting from us without our even scratching the MacKenzie Mountains and while Baffin Island develops as a romantic aberration. When housing starts drop in the United States, our forest products industry goes into a serious decline.

In manufacturing, the automobile industry is so hedged with international agreements, government guarantees, ad hoc adjustments relating to the management of the industry, and hands-across-the-border labour negotiations, that political decisions have become far more important than economic facts. Where now is Adam Smith's Unseen Hand?

In sharp contrast. the service industries are bearing up well, especially in electronics. The conventional bucolic hamlet image of the Ottawa Valley is giving way to the silicone chip: robots have returned from the wars, to enter the world of work. 


\section{WHO'S RUNNING THE SHOP?}

We know our economy is out of control. Governments admit it publicly and entrepreneurs acknowledge it in private. The world economy is out of control, and we are part of it.

If that is not so, who is in charge? It is not the world bankers. Argentina and Mexico have not been salvaged by masterful decisions of international grey eminences. Those decisions were the product of circumstances to which the decision-makers reacted with no real choice. The commodity cartels are not in control. The petroleum exporting countries combined in reaction to incredibly short-sighted managerial decisions in high energy consuming industrial countries. Those countries have had time to adjust to OPEC policies, and those policies are being challenged. Not only are the industrial countries not in control, but the developing countries are trying in an incoherent way to make them march to the drum of the New International Economic Order.

Domestically, our industrial relations system is based on the theory that the countervalence of the power of organized labour against the prevailing power of management will produce a just result. But we know that the strength and direction of those blocks of power are subject to so many variables that the vector of justice seems to be the sum of myriad injustices. Nothing reveals that so clearly as a firm swing, particularly a downward swing, in the business cycle. That, in part at least, is why management, labour and government, to say nothing of the private citizen, are in a present condition of bewilderment.

\section{RENEWAL}

The shift of the economies of industrial nations to developments in the tertiary or service sector is so pronounced that analysts now refer to the quarternary and quinary sectors to describe developments in high technology and markets for computer hardware and software. The computer world is upon us, and any one who cannot speak its language will in a few years - I daresay before I qualify for the old age pension - be considered illiterate. The roots of the post-industrial state are growing well, thank you. The world of work is being transformed. The demand for labour will not be the same again, either in total numbers or as a percentage of the labour force as the term conventionally is used, or in terms of the skills demanded.

An interdependent world will experience many spasms in many forms, of which the current recession may be but one.

That observation is not adventuresome. The industrial state in three decades of our century has produced, among other things, the convulsions of two world wars and a worldwide depression. Why should the transition to the post-industrial state be any smoother? Many conventions are being challenged - not just the statistical definition of the labour force. 
The convention most relevant to our immediate purposes is the decision-making process itself. What clearly is being challenged is both the processes of decision-making and the values which have produced them. John Kenneth Galbraith's identification of community of interests and decision-making skills of managers in industry, government and the military is now an accepted and conventional wisdom, to turn a Galbraithian expression onto its acceptance. Those interests and skills, and the conventional wisdom of the bottom line on which they are founded, are being and will be challenged as the world stumbles toward the postindustrial state.

The student disturbances of the late ' 60 s and early ' 70 s were rooted in disaffection by the young in decision-making processes. Our observation of the confrontation was clouded by the characterization as radical the events and values that produced the behaviour. That cohort in our population is now over thirty.

Collective bargaining is a process of decision-making designed as an instrument of social justice for the industrial state. Why should we not expect it to be challenged?

The challenge involves re-alignment of power and responsibility.

Hierarchical, symmetrical, centralized decision-making began giving way some time ago to a participatory search for solutions, and to decision by consensus.

Consensus requires the identity of a community of interests. Such community will be elusive in times of systemic change, particularly if we blind ourselves to the fact of change and thereby immobilize our capacity to assess and adjust.

Small is beautiful because in smallness one can find that community which is essential to consensus. Yet in an interdependent world we are being challenged to find it on a very much larger scale. After all, we are on the same space ship. The times require something more perceptive than the «antagonistic co-operation" which still characterizes our industrial relations system.

The task will not be easy. Nor will we ever be the same. 